Publisher: Taylor \& Francis \& Informa UK Limited, trading as Taylor \& Francis Group

Journal: Environmental Technology

DOI: $10.1080 / 09593330.2017 .1284268$

\title{
Electrochemical degradation and mineralization of glyphosate herbicide
}

\author{
Nam Tran ${ }^{\mathrm{a}}$, Patrick Drogui ${ }^{\mathrm{a}^{*}}$, Tuan Linh Doan ${ }^{\mathrm{b}}$, \\ Thanh Son Le ${ }^{\mathrm{b}}$, Hoai Chau Nguyen ${ }^{\mathrm{b}}$
}

a Institut national de la recherche scientifique (INRS-Eau Terre et Environnement),

Université du Québec, 490 rue de la Couronne, Québec, Qc, Canada.

b Institute of Environmental Technology, Vietnam Academy of Science and Technology (VAST), 18 Hoang Quoc Viet, Cau Giay, Hanoi, Vietnam.

* Correspondence to: Patrick Drogui, Institut national de la recherche scientifique (INRSEau Terre et Environnement), Université du Québec, 490 rue de la Couronne, Québec, PQ, Canada, G1K 9A9, Phone : (418) 654-3119, Fax : (418) 654-2600, email: patrick.drogui@ete.inrs.ca

\footnotetext{
${ }^{*}$ Corresponding author
} 
December, 2016

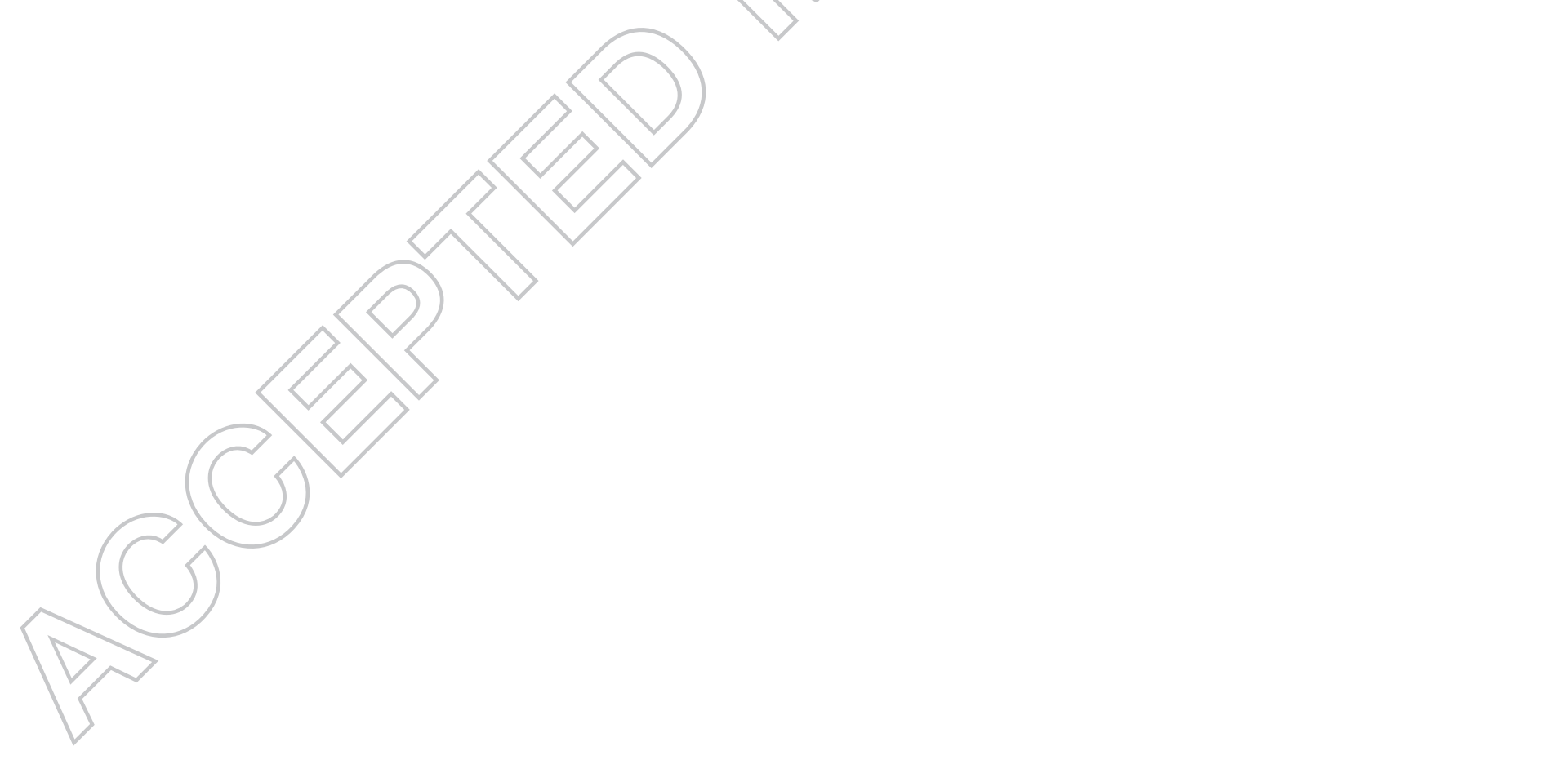




\begin{abstract}
The presence of herbicide is a concern for both human and ecological health. Glyphosate is occasionally detected as water contaminants in agriculture areas where the herbicide is used extensively. The removal of glyphosate in synthetic solution using advanced oxidation process is a possible approach for remediation of contaminated waters. The ability of electrochemical oxidation for the degradation and mineralization of glyphosate herbicide was investigated using $\mathrm{Ti} / \mathrm{PbO}_{2}$ anode. The current intensity, treatment time, initial concentration and $\mathrm{pH}$ of solution are the influent parameters on the degradation efficiency. An experimental design methodology was applied to determine the optimal condition (in terms of cost/effectiveness) based on response surface methodology. Glyphosate concentration $\left(\mathrm{C}_{0}=16.9 \mathrm{mg}\right.$ $\mathrm{L}^{-1}$ ) decreased up to $0.6 \mathrm{mg} \mathrm{L}{ }^{-1}$ when the optimal conditions were imposed (current intensity of $4.77 \mathrm{~A}$ and treatment time of $173 \mathrm{~min}$ ). The removal efficiencies of glyphosate and total organic carbon were 95 $\pm 16 \%$ and $90.31 \%$, respectively. This work demonstrates that electrochemical oxidation is a promising process for degradation and mineralization of glyphosate.
\end{abstract}

Keywords: Glyphosate; herbicide; electrochemical; degradation, mineralization. 


\section{Introduction}

Glyphosate is a broad spectrum, post-emergence organophosphorus herbicide used to control grasses and broad leaved weeds [1]. Recently, a widely use of the herbicides has raised increasing concern due to their enormous pollution of the environment. Data showed that less than $0.1 \%$ of the chemicals used for pest control will reach their target [2]. Thus, more than $99.9 \%$ of pesticides used has tendency move into the environment where they may adversely contaminate soil, water, and the atmosphere of the ecosystem [2]. In particular, glyphosate is among the most intensive used pesticides worldwide; according to the statistic forecast, the global market for glyphosate is expected to use 1.35 million tons annually [3]. Glyphosate can be found in surface and ground waters by direct use or by runoff or leaching from terrestrial applications. In Canada, glyphosate concentration as high as $5.153 \mathrm{mg} \mathrm{L}^{-1}$ were measured in runoff water after direct aerial application [4]. In the USA, pond water contained $0.09-1.7 \mathrm{mg}$ $\mathrm{L}^{-1}$ of glyphosate and 2-35 $\mu \mathrm{g} \mathrm{L}^{1}$ of amino methyl phosphonic acid (AMPA) has been detected [5]. Several countries, including the United States, Canada, and Brazil have recorded some negative effects on human and animal health due to the glyphosate contamination in water [610]. Some studies reported that herbicides are entering the aquatic system, although in extreme low concentrations may introduce a potential hazard for human, in particular where no advanced water treatments facility are used [11]. The WHO (World Health Organization) has set the recommendation concentration of glyphosate alone or in combination with AMPA of $0.9 \mathrm{mg} \mathrm{L}^{-1}$ for drinking water [12] and the Environment Canada also set a limit of $0.8 \mathrm{mg}_{\text {glyphosate }} \mathrm{L}^{-1}$ for the protection of aquatic life [13]. The existence of glyphosate in the aquatic environment requires developing methods for its removal from water. Conventional methods often used in 
water treatment plant, such as physicochemical, biological are sometime ineffective for removing herbicides $[1,14]$. Existing advanced water treatment techniques include filtration using sand, ultra filtration, reverse osmosis, adsorption by activated charcoal and biological degradation are expensive and require large infrastructure investments and some are specific to particular contaminants [10]. Advanced oxidation processes (AOPs) can be proposed to remove from water and wastewaters many refractory and toxic contaminants [15]. During AOPs, hydroxyl radical species $(\cdot \mathrm{OH})$ are used as powerful oxidizing agents. These species are shortlived, highly reactive and able to oxidize many organic pollutants in water. Recent studies show that glyphosate treatment can be degraded through some other AOPs such as UV radiation, photocatalytic $\left(\mathrm{UV} / \mathrm{TiO}_{2}\right)$ and electrochemical oxidation. The treatment using $\mathrm{UV}$ alone can be ineffective for glyphosate and AMPA oxidation. The combination of UV with $\mathrm{H}_{2} \mathrm{O}_{2}$ induced a good degradation of glyphosate, but not effective for AMPA, [11]. For instance, herbicide glyphosate was removed from water using $\mathrm{UV} / \mathrm{H}_{2} \mathrm{O}_{2}$ system: after $5 \mathrm{~h}$ of UV irradiation (40W), Manassero, Passalia, Negro, Cassano and Zalazar [16] has found a glyphosate degradation rate approximately of $80 \%$ and a percentage of mineralization of $29 \%$ were recorded (with an initial concentration of $41 \mathrm{mg}$ glyphosate $\mathrm{L}^{-1}$ in the presence of $83 \mathrm{mg} \mathrm{L}^{-1}$ of hydrogen peroxide) [16]. Likewise, glyphosate can be significantly oxidized using $\mathrm{UV} / \mathrm{TiO}_{2}$ system, but it requires a long treatment fime. Kongsong, Sikong, Niyomwas and Rachpech [17] have studied glyphosate degradation using photocatalytic by $\mathrm{N}$-Doped $\mathrm{SnO}_{2} / \mathrm{TiO}_{2}$ thin-film-coated glass fibers. It took approximately $11 \mathrm{~h}$ to degrade glyphosate from $16.9 \mathrm{mg} \mathrm{L}^{-1}$ to $0.7 \mathrm{mg} \mathrm{L}^{-1}$ using a power of UVlamp of $110 \mathrm{~W}$ (black light), a wavelength ranging between 310 and $400 \mathrm{~nm}$ with a distance between light source and substrate of $32 \mathrm{~cm}$. In spite of the high oxidation rate of glyphosate, longer treatment time and the relatively higher treatment costs hamper the development of 
photocatalytic processes at large scale applications [18]. Therefore, research has focused on electrochemical oxidation process, which has several advantages such as easy control, no chemical added and highly effective removal of organic and inorganic compounds. Electrochemical oxidation process generates a very efficient oxidizing environment by forming hydroxyl radicals, providing effective water purification for elimination of persistent organic pollutants. Electrochemical oxidation is also able to oxidize organic pollutants into $\mathrm{CO}_{2}$ and $\mathrm{H}_{2} \mathrm{O}$. This allows avoiding the problem of pollutant transfer from one phase to another. Neto and De Andrade [7] has studied glyphosate oxidation by using dimensionally stable anodes in chloride medium. After $4 \mathrm{~h}$ of electrolysis with anode $\mathrm{Ti} / \mathrm{Ir}_{0.30} \mathrm{Sn}_{0.70} \mathrm{O}_{2}$, a complete glyphosate removal from the electrolyzed solution $\left(\mathrm{C}_{0}=1000 \mathrm{mg} \mathrm{L}^{-1}\right)$ was achieved. In the chloride matrix, application of $50 \mathrm{~mA} \mathrm{~cm}{ }^{-2}$ leads to nearly total mineralization (release of phosphate ions=91\%). However, chlorination will be inappropriate, notably from the associated risk of forming toxic by-products such as organochlorinated compounds.

In this study, the electrochemical oxidation of glyphosate is proposed. The destruction and mineralization of herbicides in waters using the electrochemical oxidation has been presented in the literature. However, to the best of our knowledge, this is the first time that the electrochemical oxidation has been applied without the presence of chloride (as supporting electrolyte) to solye the challenging problem of efficient degradation of glyphosate. Thus the aims of this study are: $i$ ) to evaluate the feasibility of using this approach for degradation and mineralization of glyphosate from water without adding chloride as supporting electrolyte; $i$ ) to use statistical methodology approach in order to determine the optimal conditions for glyphosate degradation and; iii) to propose a reaction pathway (mechanism) for glyphosate degradation based on the identified by-products. 


\section{Materials and methods}

\section{Sample Preparation}

The synthetic solution was prepared by dissolving glyphosate powder $\left(\mathrm{C}_{3} \mathrm{H}_{8} \mathrm{NO}_{3} \mathrm{P}\right.$; CAS $\# 1071-$ 83-6) in ultrapure water (18 M $\left.\Omega \cdot \mathrm{cm}^{2}\right)$. Glyphosate (Sigma Aldrich, NY, USA) used in this study was a reagent grade with purity $\geq 96 \%$ (Table 1 ).

[Table 1 near here]

The stock solution of glyphosate was prepared by dissolving $1.69 \mathrm{~g}$ of glyphosate in $1.0 \mathrm{~L}$ of ultrapure water. Solubilisation was carried out at $500 \mathrm{rpm}$ for $10 \mathrm{~min}$. The synthetic sample were prepared by taking desired amounts of stock solution in glass beakers and mixing with ultrapure water to reach final concentrations ranging between 4.3 and $33.8 \mathrm{mg} \mathrm{L}^{-1}$ in which a sodium salt $\left(\mathrm{Na}_{2} \mathrm{SO}_{4} 0.01 \mathrm{~mol} \mathrm{~L}^{-1}\right)$ was added to increase electrical conductivity.

\section{Electrochemical reactor set-up}

The electrochemical oxidation of glyphosate was performed in batch mode with operation using an electrolytic reactor made of Plexiglas having a dimension of $21 \mathrm{~mm}$ (width) $\times 150 \mathrm{~mm}$ (length) $\times 180 \mathrm{~mm}$ (height). A schematic view of the experimental unit can be seen in Fig. S1 (Supplementary data). The electrode sets was comprised of one cathode and one anode with a distance between the electrodes of $10 \mathrm{~mm}$. The electrodes were vertically installed inside the reactor. The anode used in this study was $\mathrm{Ti} / \mathrm{PbO}_{2}$ (lead oxide coated on titanium) and cathode was made of Ti. The preparation of this anode was described elsewhere (Didier et al, 2003). Both electrodes were in form of rectangular mesh with a dimension of $100 \mathrm{~mm} \times 110 \mathrm{~mm}$. A digital DC power supply VSP4030 (B\&K Precision, CA, US) was used to apply the current intensity. 
The agitation inside the electrolytic cell was carried out by recirculating water through the reactor in a continuous mode by means of a pump (operated at a constant speed of $1000 \mathrm{~mL} \mathrm{~min}^{-}$ $\left.{ }^{1}\right)$. In all experiments, a total volume of $1.0 \mathrm{~L}$ of sample was used. The working volume of the reactor was $550 \mathrm{~mL}$, compared to $450 \mathrm{~mL}$ required in the recycling tank.

\section{Electrochemical oxidation of the glyphosate solution}

\section{Preliminary experiments}

The first step of electrochemical oxidation experiments was used to investigate the effects of the main factors (current applied, $\mathrm{pH}$, treatment time and initial pollutant concentration) in treating water contained glyphosate. During these tests, the residual concentrations of glyphosate and residual TOC concentrations were measured to examine the performance of the electrochemical unit. The current intensities ranged from $0.5 \mathrm{~A}$ to $10.0 \mathrm{~A}$ (current densities from $4.55 \mathrm{~mA} \mathrm{~cm}{ }^{-2}$ to $90.9 \mathrm{~mA} \mathrm{~cm}{ }^{-2}$ ). The treatment time up to 360 min was tested. The effect of the initial glyphosate concentration $\left(4.3,8.9,16.9\right.$ and $\left.33.8 \mathrm{mg} \mathrm{L}^{-1}\right)$ was studied. Likewise, the effect of $\mathrm{pH}$ value was tested in the range 3-10 using a glyphosate concentration of $16.9 \mathrm{mg} \mathrm{L}^{-1}$ and their effectiveness was compared with the initial $\mathrm{pH}$ (solution without $\mathrm{pH}$ adjustment).

\section{Experimental design}

The degradation of glyphosate by electrochemical was carried out using response surface methodology (RSM). A central composite design methodology (CCD) was used to optimize the glyphosate degradation using the electro-oxidation process. Two major independent variables were used in this study based on preliminary experiments: treatment time and current intensity. 
A two-factorial design completed by a central composite design (at two-levels), with five replicates at the center of the experimental region for each numeric factor, led to a total number of thirteen experiments employed for response surface modeling. The experimental range and levels of independent variables investigated for glyphosate degradation with the coded values are shown in Table 2.

[Table 2 near here]

The values of the variables and their variation limits were selected based on preliminary experiments. During these experiments, the glyphosate removal efficiency was used to evaluate the effectiveness of the process. Experimental data were collected from the average of at least of three replicates. Uncertainties were removed and calculated at a significance level of $p \leq 0.05$. The analysis of variance and other statistical data were calculated and generated using the Design Expert Software version 7.2 (Stat-Ease Ine., USA).

\section{Solution Analyses}

\section{Glyphosate measurements}

The concentrations of glyphosate (before and after the treatment) were firstly monitored by absorbance measurements using a spectrophotometer Carry UV 50 (Varian Canada Inc.) for ease of analysis during preliminary and optimization step. The method used to analysis glyphosate was described previously [19]. The test is based on the reaction of ninhydrin with glyphosate in presence of sodium molybdate in neutral aqueous medium to make a Ruhemann's purple product (having the VIS absorption maximum at $570 \mathrm{~nm}$ ). A stock of $100 \mathrm{mg} \mathrm{mL}^{-1}$ solution was used to prepare standard sample containing different concentrations of the glyphosate $(1.0,5.0,10.0$, 15.0, 25.0, and $35.0 \mathrm{mg} \mathrm{L}^{-1}$ ) which were then added to separate test tubes containing $1 \mathrm{~mL}$ of 
ninhydrin $\left(5 \%, \mathrm{~m} \mathrm{v}^{-1}\right)$ and $1 \mathrm{~mL}$ of sodium molybdate $\left(5 \%, \mathrm{~m} \mathrm{v}^{-1}\right)$. The mixtures were placed in a water bath at $100^{\circ} \mathrm{C}$ for $5 \mathrm{~min}$ and cooled naturally to ambient temperature, and made up to 10 $\mathrm{mL}$ in volumetric flasks. A calibration curve of known glyphosate concentrations (0.0-3.5 mg L $\left.{ }^{1}\right)$ versus absorbance was used to calculate the residual glyphosate concentration and define the effluent (Fig. S2, Supplementary data). The detection limit of this technique was $0.1 \mathrm{mg}^{-1}$. However, when the optimal conditions were determined and repeated in triplicate to verify the effectiveness and the reproducibility of the electrooxidation process, the residual concentration of glyphosate and its by-products were analyzed by liquid chromatography/mass spectrometry technique (LC-MS) rather than UV-VIS spectroscopic. The analyses of glyphosate and AMPA were carried out using a Thermo Scientific Finnigan ${ }^{\mathrm{TM}}$ LC/MS system. The separations were performed using $50 \times 2.1 \mathrm{~mm}$ chromatographic columns; $5 \mu \mathrm{m}$ particle size Thermo Scientific Hypersil $^{\mathrm{TM}}$ BDS C18 and $5 \mu \mathrm{m}$ particle size Hypercarb. Two mobile phases (A and B) were used during analysis: $0.1 \%$ formic acid in water (Phase A) and $0.1 \%$ formic acid in acetonitrile (Phase B). The injection of the two mobile phases was gradient programmed as follows 5 to $100 \%$ (Phase B) in $10 \mathrm{~min}$ and the injection flow rate was $0.3 \mathrm{ml} \mathrm{min}{ }^{-1}$. The formation of reaction intermediates was monitored by using TSQ Quantum Access mass spectrometry (Thermo Scientific, USA) equipped with an electrospray ionization source operated in the positive ion mode. Analysis was performed in Selected Ion Monitoring (SIM) mode. Nitrogen was used as a sheath and auxiliary gas. Working conditions were as followed: spray voltage was $4500 \mathrm{~V}$ and capillary temperature was $450^{\circ} \mathrm{C}$. Calibration standards were prepared by serial dilution of the intermediate solutions $(1 \mathrm{ppm})$ in water at concentrations of $2 \mu \mathrm{g} \mathrm{L}^{-1}-100 \mu \mathrm{g} \mathrm{L}^{-1}$ with sulfamethazine $\mathrm{C}_{13}$ was used as internal standard. The limit of detection was $1.0 \mu \mathrm{g} \mathrm{L}^{-1}$. 


\section{Operating parameters and other measurements}

The $\mathrm{pH}$ and conductivity were monitored using a $\mathrm{pH} / \mathrm{Cond}$ meter (Accumet Research model AR 25) equipped with a $\mathrm{pH}$ and conductivity probe. Total organic carbon was measured using a Shimadzu TOC-V $\mathrm{V}_{\mathrm{CPH}}$ analyser (Shimadzu Scientific Instruments, Kyoto, Japan). Ammonium ions were measured by ammonium ion selective electrodes (Cole Parmer) using a pH/ion-meter (Accumet Research model AR 25 Dual Channel pH/Ion meter, Fisher Scientific). The ionic strength adjuster $(5 \mathrm{M} \mathrm{NaCl})$ was added $(2 \mathrm{ml}$ to every $100 \mathrm{ml}$ of sample $)$ to keep a constant background ionic strength present in the solution. Concentrations were measured with an incertitude of $\pm 5 \mathrm{mg} / \mathrm{L}$. Nitrate ions were measured by nitrate ion selective electrodes (Cole Parmer) using a pH/ion-meter (Accumet Research model AR 25). The ionic strength adjuster $\left(2 \mathrm{M}\left(\mathrm{NH}_{4}\right)_{2} \mathrm{SO}_{4}\right)$ was also added at rate of $2 \mathrm{ml}$ to every $100 \mathrm{ml}$ of sample. Concentrations were measured with incertitude of $\pm 5 \mathrm{mg} \mathrm{L}^{-1}$. Phosphate ions were quantified by plasma emission spectroscopy (ICP-AES) with a Varian apparatus (Vista AX model, Alto, California).

\section{Economic aspect}

The economic study included the consideration of chemical and energy consumption. The electric cost was estimated to be approximately $0.06 \mathrm{US} \$ \mathrm{kWh}$. The energy consumption, Ec $(\mathrm{kWh})$, calculated by multiplying the current applied, I (A), by the cell voltage, $\mathrm{U}_{C}(\mathrm{~V})$, and taking into account the treatment time $\mathrm{t}(\mathrm{h})$, can be expressed by the following equation:

$$
E_{c}(k W h)=\frac{U_{C} \cdot I . t}{1000}
$$

The unit cost of the electrolyte $\left(\mathrm{Na}_{2} \mathrm{SO}_{4}\right.$ industrial grade) was $0.30 \mathrm{US} \$ \mathrm{~kg}^{-1}$. The total cost was evaluated in terms of US\$ spent per $\mathrm{m}^{3}$ of treated solution. 


\section{Results and discussion}

\section{Effect of the current intensity}

The effect of the current density on the electrooxidation of glyphosate was eyaluated by measuring the residual glyphosate concentration at current intensity of $10 \mathrm{~A}, 5 \mathrm{~A}, 3 \mathrm{~A}, 2 \mathrm{~A}, 1.5 \mathrm{~A}$, 1A and 0.5A. The initial glyphosate concentration was $0.1 \mathrm{mmol} \mathrm{L}^{-1}\left(16.9 \mathrm{mg} \mathrm{L} \mathrm{L}^{-1}\right)$ and the treatment time was fixed at $180 \mathrm{~min}$. Fig. 1 shows degradation efficiency as a function of the current intensity imposed. The degradation efficiencies were $93.3 \%, 94.1 \%, 96.5 \%, 96.6 \%$, $97.3 \%, 97.4 \%$ and $97.4 \%$ for $0.5 \mathrm{~A}, 1 \mathrm{~A}, 1.5 \mathrm{~A}, 2 \mathrm{~A}, 3 \mathrm{~A}, 5 \mathrm{~A}$ and $10 \mathrm{~A}$, respectively. The efficiency of glyphosate degradation increased with the current intensity imposed, the higher the current intensity, the more effective of removal and the lower residual glyphosate concentration. More than $96 \%$ of glyphosate was degraded for a current intensity higher than $1.5 \mathrm{~A}$ and the residual concentration of glyphosate was below the limiting values $\left(0.8 \mathrm{mg} \mathrm{L}^{-1}\right)$ recommended for the fresh water by Environment/Canada[12]. However the efficiency of glyphosate degradation increased with current intensity until 3.0A and then remained quite stable around $97 \%$ from $3.0 \mathrm{~A}$ to $10.0 \mathrm{~A}$. It can be explained that the anodic oxidation of glyphosate occurred heterogeneously. Glyphosate must be moved to the electrode surface (anode) and then be oxidized there. As the glyphosate concentration was lowered to a certain level, only a fraction of current intensity supplied was used to oxidize pollutants, while the remaining charge loading was wasted for generation of oxygen [20]. It was the reason for which the efficiency of glyphosate degradation remained stable in spite of high current applied. The residual glyphosate concentrations recorded at the end of the treatment varied from $0.43 \mathrm{mg} \mathrm{L}^{-1}$ to $1.14 \mathrm{mg} \mathrm{L}^{-1}$, compared with $16.9 \mathrm{mg} \mathrm{L}^{-1}$ initially imposed in the raw effluent. The same trend was also 
obtained for TOC removal. As the current intensity increased, the mineralization rate became higher. The residual TOC concentrations recorded at the end of the treatment varied from 0.129 $\mathrm{mg} \mathrm{L} \mathrm{L}^{-1}$ to $0.833 \mathrm{mg} \mathrm{L}^{-1}$, compared to $2.878 \mathrm{mg} \mathrm{L}^{-1}$ initially measured. The percentage of oxidizable carbon (mineralised C-CO $\mathrm{CO}_{2}$ ) for the total carbon in the final solution after 180 min at 0.5A, $1 \mathrm{~A}, 1.5 \mathrm{~A}, 2 \mathrm{~A}, 3 \mathrm{~A}, 5 \mathrm{~A}$ and $10 \mathrm{~A}$ were $71.1 \%, 77.0 \%, 78.2 \%, 85.3 \%, 85.7 \%, 94.0 \%$ and 95.5\%, respectively. This confirmed that as the current intensity increased, the degradation efficiency also increased. When high current intensities were applied (i.e., 5 and $10 \mathrm{~A}$ ), the mineralization of oxidizable carbon was relatively high, compared to the percentages of mineralization (TOC abatement) recorded for low current intensities $(0.5 \mathrm{~A}-3 \mathrm{~A})$. This suggests that as the glyphosate concentration was lowered to a certain level, its by-products were formed. The degradation of glyphosate and its by-products pursued until total mineralization occurred due to the electrophilic attack of oxidising species which are generated electrochemically. It is well known that those generated species react favourably with electron-rich compounds [20]. In fact, hydroxyl radicals species break the bonds (-C-N- and -C-P-), which are the major component of glyphosate and its by-product leading to higher oxidation rates and possible mineralization of organic matter. Using a current intensity of $5.0 \mathrm{~A}$, the rates of glyphosate degradation $(97 \%)$ were quite high similar to the percentage of TOC removal $(94 \%)$, so the current intensity of 5.0 A was used for the next experiments.

\section{Effect of treatment time}

It has been established that the treatment efficiency is greatly affected by the operating conditions such as the reaction time and the cost of the electrochemical process $[20,21]$. In order to reduce the energy consumption and further optimize the process, additional experiments were 
conducted by testing various retention times. These tests were performed at a constant current intensity of 5A and different treatment times (5, 20,30,60, 120, 180 and $360 \mathrm{~min})$. The initial glyphosate concentration was $0.1 \mathrm{mmol} \mathrm{L}^{-1}\left(16.9 \mathrm{mg} \mathrm{L}^{-1}\right)$ and the supporting electrolyte was $\mathrm{Na}_{2} \mathrm{SO}_{4}\left(0.01 \mathrm{mmol} \mathrm{L}^{-1}\right)$. The variation of residual glyphosate and TOC concentrations against the retention time are shown in Fig. 2. Three regions could be observed in the (residual glyphosate concentration, time) and (residual TOC concentration, time) planes. In fact, the residual glyphosate concentration decreased rapidly during the first 60 min of treatment; then, it decreased slowly with a relatively low slope from 60 to $180 \mathrm{~min}$ and remained steady beyond 180 min. During these experiments, an initial glyphosate concentration of $16.9 \mathrm{mg} \mathrm{L}^{-1}$ was imposed compared to $0.43 \mathrm{mg} \mathrm{L}^{-1}$ recorded at $360 \mathrm{~min}$ (glyphosate removal of $97.5 \%$ ). The TOC was more difficult to remove in the first region $(0-60 \mathrm{~min})$ owing to the complexity of both glyphosate and its by-products. The TOC concentrations obtained at the end of electrooxidation were $0.13 \mathrm{mg} \mathrm{L}^{-1}$, whereas the initial TOC concentration was $2.9 \mathrm{mg} \mathrm{L}^{-1}$. The experimental data were well fitted with the first-order kinetic (with a correlation coefficients ranging from 0.88 to 0.95; Fig. S3, Supplementary data) predicting a linear variation against time $(\mathrm{t})$ of the $-\mathrm{Ln}\left(\mathrm{C} / \mathrm{C}_{0}\right)$

$-\operatorname{Ln}\left(\frac{C}{C_{0}}\right)=k . t$

where $C$ is the concentration of glyphosate at time $t, C_{0}$ is the initial concentration of glyphosate $k$ is the pseudo-first-order degradation rate constant. The reaction rate apparent constants obtained were the followings: $0.044 \mathrm{~min}^{-1}$ (for glyphosate removal) and $0.024 \mathrm{~min}^{-1}$ (for TOC removal). The relatively high mineralization rate (95\%) confirmed that a non-negligible part of glyphosate compound was oxidized into water $\left(\mathrm{H}_{2} \mathrm{O}\right)$ and carbon dioxide $\left(\mathrm{CO}_{2}\right)$. It is worth noting that, during electrolysis, organic pollutants can be subjected to two different paths in 
anodic oxidation: electrochemical conversion or electrochemical combustion [21, 22]. Electrochemical conversion only transforms the organic pollutants into biodegradable compounds, whereas electrochemical combustion oxidised the organic pollutants to form $\mathrm{H}_{2} \mathrm{O}$ and $\mathrm{CO}_{2}$ and no further treatment is then required. When the treatment time was increased, hydroxyl radical concentrations generated at the surface of anode increased and it contributed to glyphosate degradation. After $180 \mathrm{~min}$ of treatment time, the percentage of glyphosate removal remained quite stable owing to competitive reactions (parasitic reactions) and hydroxyl radical formation was limited. A treatment time of 120 min was required to reach a residual glyphosate concentration below the limiting values $\left(0.8 \mathrm{mg} \mathrm{L}^{-1}\right)$ recommended by the Canadian Environment Agency. Therefore 120 min of treatment time was selected for the next step of the study.

\section{Effect of the pH}

The change in initial $\mathrm{pH}$ can be useful to enhanced the degradation efficiency and further optimize the treatment. To examine the effect of $\mathrm{pH}$, various $\mathrm{pH}$ from 3-10 was investigated for a fixed glyphosate concentration $\left(0.1 \mathrm{mmol} \mathrm{L}^{-1}\right)$. The electro-oxidation experiments were applied at a current intensity of 5.0A. $\mathrm{NaOH}$ and $\mathrm{H}_{2} \mathrm{SO}_{4}$ were used to adjust the $\mathrm{pH}$ values of the solutions. Fig. 3 shows that after $120 \mathrm{~min}$ of treatment, the glyphosate degradation and mineralization rate was higher in acidic medium. The highest rates of glyphosate removal $(95.5 \%)$ and TOC removal $(85.7 \%)$ were recorded at $\mathrm{pH}=3$ compared to the initial solution without $\mathrm{pH}$ control $(\mathrm{pH}=4.22 ; 95 \%$ of glyphosate and $80.2 \%$ of TOC removal). It is worth noting that, in all cases with $\mathrm{pH}<5$, residual glyphosate concentrations were below the limiting values $\left(0.8 \mathrm{mg} \mathrm{L}^{-1}\right)$. Glyphosate compound has the characteristics of a ternary acid, which has 
four ionization constants $\mathrm{pK}_{\mathrm{a} 1}=0.8\left(1^{\text {st }}\right.$ phosphonic $), \mathrm{pK}_{\mathrm{a} 2}=2.6$ (carboxylate), $\mathrm{pK}_{\mathrm{a} 3}=5.6\left(2^{\text {nd }}\right.$ phosphonic) and $\mathrm{pK}_{\mathrm{a} 4}=10.6$ (amine) [8]. This molecule has an electrical charges in function of $\mathrm{pH}$ of solution. These results are consistent with those obtained by Aquino Neto and de Andrade [23] while treating glyphosate (1000 $\mathrm{mg} \mathrm{L}^{-1}$ solution) using an electrochemical oxidation process. After $4 \mathrm{~h}$ of electrolysis $\left(i=50 \mathrm{~mA} \mathrm{~cm}^{-2}\right.$, electrolyte $\left.=\mathrm{Na}_{2} \mathrm{SO}_{4}\right)$, the degradation rate of glyphosate decreased with the increase of $\mathrm{pH}$. The highest degradation rate (34\%) was obtained at approximately $\mathrm{pH}=2$, compared to $18 \%$ recorded for $\mathrm{pH}=11$. Thus, to easily reach a residual concentration of glyphosate below the acceptable level recommended for fresh water and to avoid adding chemical during electrolysis, a treatment without $\mathrm{pH}$ control was selected for the next step of the experiments.

\section{Effect of the initial glyphosate concentration}

It is well known that the initial contaminant concentration can influence electrochemical oxidation processes. To verify these assumptions, complementary experiments with different initial concentrations of glyphosate: $4.3,8.9,16.9$ and $33.8 \mathrm{mg} \mathrm{L}^{-1}$ (from $0.025 \mathrm{mmol} \mathrm{L}^{-1}$ to 0.2 mmol L-1) were studied. During these assays, a current intensity of $5 \mathrm{~A}$ was applied without $\mathrm{pH}$ adjustment during $120 \mathrm{~min}$. Residual glyphosate concentration and TOC concentrations were measured. Fig. 4 presents the changes in the normalized concentration for glyphosate (4a) and TOC (4b) in function with time. This result indicated that glyphosate electrochemical oxidation and mineralization rate increased when the initial glyphosate concentration increased. The limiting values $\left(0.8 \mathrm{mg} \mathrm{L}^{-1}\right)$ recommended by the Canadian Environment Agency could not be reached after $120 \mathrm{~min}$ of oxidation with the initial concentration of $33.8 \mathrm{mg} \mathrm{L}^{-1}$. However, for the other initial concentrations, the limiting value recommended by the Canadian Environment 
Agency could be reached. A minimum of $0.68 \mathrm{mg} \mathrm{L}^{-1}$ of glyphosate was recorded when the initial concentration imposed was $4.3 \mathrm{mg} \mathrm{L}^{-1}$. Additionally, the maximum percentage of mineralization of $87.4 \%$ was obtained (at an initial concentration of $33.8 \mathrm{mg} \mathrm{L}^{-1}$ ) compared to those recorded: $85.6 \%\left(\mathrm{C}_{0}=16.9 \mathrm{mg} \mathrm{L}^{-1}\right), 83.0 \%\left(\mathrm{C}_{0}=8.9 \mathrm{mg} \mathrm{L}^{-1}\right)$ and $75.2 \%\left(\mathrm{C}_{0}=4.3 \mathrm{mg} \mathrm{L}^{-1}\right)$.

\section{Optimization of glyphosate degradation and economical aspect}

CCD was used to optimize the electrochemical process for glyphosate degradation. A two-level central composite experimental design, with five replicates at the center point leading to a total number of thirteen experiments was used for response surface modelling (Table 3).

[Table 3 near here]

The CCD matrix is comprised of three parts: factorial matrix (assays 5, 6, 12, 13), a star matrix (assays 1, 3, 8, 11) and a group of points at the center of the experiments (assays 2, 4, 7, 9, 10). The response was described by a second-order model in the form of quadratic polynomial equation given below:

$$
Y=b_{0}+\sum_{i=1}^{k} b_{i} \cdot X_{i}+\sum_{i=1}^{k} b_{i i} \cdot X_{i}^{2}+\sum_{j} \sum_{i=2}^{k} b_{i j} \cdot X_{i} X_{j}+e_{i}
$$

where $\mathrm{Y}$ is the experimental response; $\mathrm{X}_{\mathrm{i}}$ and $\mathrm{X}_{\mathrm{j}}$ are the independent variables; $\mathrm{b}_{0}$ is the average of the experimental response; $b_{i}$ is the estimation of the principal effect of the factor $i$ on the response $Y ; b_{j}$ is the estimation of the second effect of the factor $j$ on the response $Y$; $b_{i j}$ is the estimation of the interaction effect between $i$ and $j$ on the response $\mathrm{Y}$ and $\mathrm{e}_{\mathrm{i}}$ represents the error on the response Y. All coefficients are calculated using the least square method [24]. 
The coefficients of the polynomial model (quadratic model) were calculated using the DesignExpert $^{\circledR}$ Program Software; the regression model has been presented by the following equation for each response (residual glyphosate concentration and mineralization efficiency, respectively) in terms of coded variables:

$$
\begin{aligned}
& Y_{\text {glyph }}=1.28-0.23 X_{1}-0.22 X_{2}+0.11 X_{1} X_{2}-0.16 X_{1}^{2}-0.12 X_{2}^{2} \\
& Y_{\text {TQG }}=81.84+5.43 X_{1}+7.43 X_{2}-2.28 X_{1} X_{2}+0.56 X_{1}^{2}-1.61 X_{2}^{2}
\end{aligned}
$$

The analysis of variance indicates that the model is significant for glyphosate and TOC removal (Section S3, Supplementary data). The value of the correlation coefficient for glyphosate removal $\left(\mathrm{R}^{2}=0.9219\right)$ indicates that only $7.81 \%$ of the total variation could not be explained by the empirical model. The agreement between actual and predicted values of glyphosate removal is satisfactory and consistent with the statistical significance of the quadratic model. To rigorously determine the optimal conditions for glyphosate degradation in terms of cost and effectiveness, the criteria selected for the optimization condition for glyphosate degradation are the following: $i$ ) treatment time and current intensity have to be minimized with a relatively high importance (3/5 weighting factor) in order to reduce the treatment cost (including the energy cost); $i$ ) the percentage of TOC degradation must be maximized with the high importance $(3 / 5$ weighting factor); iii) the final concentration of glyphosate degradation must be lowered than recommend value $\left(0.8 \mathrm{mg} \mathrm{L}^{-1}\right)$ with the highest importance (5/5 weighting factor). Based on these criteria, the Design Expert Program Software proposed several interesting solutions to obtain a high degradation of glyphosate. The optimal conditions for glyphosate degradation in terms of cost/effectiveness were established as follows: 173 min of treatment using a current 
intensity of $4.77 \mathrm{~A}$ and the theoretical response proposed for TOC degradation was $90.28 \%$ whereas the residual concentration was $0.69 \mathrm{mg} \mathrm{L}^{-1}$ for the glyphosate.

According to the results mentioned above, the electrolytic reactor that carried out at a current applied of $4.77 \mathrm{~A}$ for $173 \mathrm{~min}$ of treatment with initial concentration of $16.9 \mathrm{mg} \mathrm{L}^{-1}$ glyphosate gave the best performance of electro-oxidation of glyphosate. It was now important to determine whether the results of these tests are reproducible. Thus, the optimal assay (determined in terms of effectiveness and cost) was repeated in triplicate to verify the effectiveness and reproducibility of electro-oxidation performance in treating waters contaminated by glyphosate in the presence of $\mathrm{Na}_{2} \mathrm{SO}_{4}$ as electrolyte. Table 4 compares the untreated and the electro-oxidation-treated water. An average glyphosate concentration of $12.4 \pm 0.5 \mathrm{mg}^{-1}$ was measured in influent water (control assay).

[Table 4 near here]

The control assay consisted only of agitating the synthetic glyphosate solution in the electrolytic cell without imposing any current density. By comparison, the application of electrochemical treatment reduced the concentration of glyphosate to an average value of $0.6 \mathrm{mg} \mathrm{L}^{-1}$ (with a standard deviation of $0.25 \mathrm{mg} \mathrm{L}^{-1}$ ) which means that it can be supposed as accuracy constant of $7.81 \%$. Finally, the glyphosate removal efficiency had a mean value of $95.16 \%$ at the optimal conditions $(\mathrm{I}=4.77 \mathrm{~A}, \mathrm{t}=173 \mathrm{~min})$ given a treatment cost of $\$ 6.33 \mathrm{~m}^{-3}(\$ 1.08$ per gram of glyphosate removed). 


\section{Conclusions}

This study has shown the possibility of using an electrochemical technique to efficiently oxidize glyphosate (4-16 mg L $\left.{ }^{-1}\right)$ using $\mathrm{Ti} / \mathrm{PbO}_{2}$ anode. The first part of these works showed that the current intensity, treatment time, $\mathrm{pH}$ and initial concentration are the most influent parameters. The used of $\mathrm{Na}_{2} \mathrm{SO}_{4}$ as a supporting electrolyte was useful to take away the risk of formation of toxic by-products during electrolysis compared to other sodium salts (e.g., NaCl). Moreover, a CCD was employed to define the optimal operating conditions for glyphosate degradation. The electrochemical reactor operated at current intensity of $4.77 \mathrm{~A}$ and treatment time of $173 \mathrm{~min}$ was found to be the optimal conditions in terms of energy consumption/effectiveness. At this condition, glyphosate could be diminished by up to $95 \%$ and $90 \%$ of TOC could be removed in which the residual concentration of glyphosate $\left(0.6 \mathrm{mg} \mathrm{L}^{-1}\right)$ in the treated water was below the acceptable level recommended by the Canadian Environment Agency. Likewise, glyphosate decomposition based on the identified by-products exhibited that total mineralisation has been achieved. The total treatment cost was estimated to $\$ 1.08$ per gram of glyphosate removed which showed a potential technology that can be used as advanced treatment to remove herbicides and other contaminants from water.

\section{Acknowledgements}

Sincere thanks are extended to Dr. Viet Hoang Nguyen, Institute of Environmental Technology, VAST for the laboratory facilities and technical support to this study. Nam Tran also acknowledges the financial support from Mitacs Globalink (Mitcas-IT06082). 


\section{Supplementary material}

Additional tables and figures associated with this article can be found in the online version.

\section{References}

[1] A.L. Cerdeira, and S.O. Duke, The current status and environmental impacts of glyphosate-resistant crops: a review, in J. Environ. Qual., 2006, pp. 1633-58.

[2] D. Pimentel, Amounts of pesticides reaching target pests: Environmental impacts and ethics, in Journal of Agricultural and Environmental Ethics, Kluwer Academic Publishers, 1995, pp. 17-29.

[3] Foeeurope.org, Introducing Glyphosate, the world's biggest selling herbicide, Friends of the Earth Europe, Brussels, Belgium, 2013.

[4] W.M. Edwards, G.B. Triplett, and R.M. Kramer, A Watershed Study of Glyphosate Transport in Runoff, in J Environ Qual, 1980, pp. 661-665.

[5] W.A. Battaglin, D.W. Kolpin, E.A. Scribner, K.M. Kuivila, and M.W. Sandstrom, Glyphosate, other herbicides, and transformation products in midwestern streams, in Journal of the American Water Resources Association, Blackwell Publishing Ltd, 2005, pp. 323-332.

[6] W.A. Battaglin, M.T. Meyer, K.M. Kuivila, and J.E. Dietze, Glyphosate and Its Degradation Product Ampa Occur Frequently and Widely in Us Soils, Surface Water, Groundwater, and Precipitation(1), in Journal of the American Water Resources Association, 2014, pp. 275-290.

[7] S.A. Neto, and A.R. De Andrade, Electrochemical degradation of glyphosate formulations at DSA anodes in chloride medium: an AOX formation study, in Journal of Applied Electrochemistry, 2009, pp. 1863-1870.

[8] M. Xie, Z. Liu, and Y. Xu, Removal of glyphosate in neutralization liquor from the glycine-dimethylphosphit process by nanofiltration, in Journal of hazardous materials, 2010, pp. $975-80$.

[9] D.F. Tzaskos, C. Marcovicz, N.M.P. Dias, and N.D. Rosso, Development of sampling for quantification of glyphosate in natural waters, in Ciência e Agrotecnologia, 2012, pp. 399-405.

[10] R.T. Carneiro, T.B. Taketa, R.J. Gomes Neto, J.L. Oliveira, E.V. Campos, M.A. de Moraes, C.M. da Silva, M.M. Beppu, and L.F. Fraceto, Removal of glyphosate herbicide from water using biopolymer membranes, in Journal of environmental management, 2015, pp. 353-60. 
[11] J. Jonsson, R. Camm, and T. Hall, Removal and degradation of glyphosate in water treatment: a review, in Journal of Water Supply Research and Technology-Aqua, 2013, pp. 395-408.

[12] WHO, Glyphosate and AMPA in drinking-water. Background document for preparation of WHO Guidelines for drinking-water quality., World Health Organization, Geneya, 2005.

[13] EnvironmentCanada, Canadian Water Quality Guidelines for the Protection of Aquatic Life, National Guidelines and Standards Office, Gatineau, QC, 2012.

[14] L.D. Kier, and D.J. Kirkland, Review of genotoxicity studies of glyphosate and glyphosate-based formulations, in Crit Rev Toxicol, 2013, pp. 283-315.

[15] N. Tran, P. Drogui, F. Zaviska, and S.K. Brar, Sonochemical degradation of the persistent pharmaceutical carbamazepine, in Journal of environmental management, 2013, pp. 25-32.

[16] A. Manassero, C. Passalia, A.C. Negro, A.E. Cassano, and C.S. Zalazar, Glyphosate degradation in water employing the H2O2/UVC process, in Water Res, 2010, pp. 387582 .

[17] P. Kongsong, L. Sikong, S. Niyomwas, and V. Rachpech, Photocatalytic Degradation of Glyphosate in Water by N-Doped SnO2/TiO2 Thin-Film-Coated Glass Fibers, in Photochemistry and Photobiology, 2014, pp. 1243-1250.

[18] E.M.D. Kirmser, D.O. Martire, M.C. Gonzalez, and J.A. Rosso, Degradation of the Herbicides Clomazone, Paraquat, and Glyphosate by Thermally Activated Peroxydisulfate, in Journal of Agricultural and Food Chemistry, 2010, pp. 12858-12862.

[19] B.L. Bhaskara, and P. Nagaraja, Direct Sensitive Spectrophotometric Determination of Glyphosate by Using Ninhydrin as a Chromogenic Reagent in Formulations and Environmental Water Samples, in Helvetica Chimica Acta, WILEY-VCH Verlag, 2006, pp. 2686-2693.

[20] L.H. Tran, P. Drogui, G. Mercier, and J.F. Blais, Electrochemical degradation of polycyclic aromatic hydrocarbons in creosote solution using ruthenium oxide on titanium expanded mesh anode, in J Hazard Mater, 2009, pp. 1118-29.

[21] N. Tran, and P. Drogui, Electrochemical removal of microcystin-LR from aqueous solution in the presence of natural organic pollutants, in Journal of environmental management, 2013, pp. 253-60.

[22] L.H. Tran, P. Drogui, G. Mercier, and J.F. Blais, Electrolytic Oxidation of Polynuclear Aromatic Hydrocarbons from Creosote Solution Using Ti/IrO2 and Ti/SnO2 Circular Mesh Electrodes, in Journal of Environmental Engineering-Asce, 2009, pp. 1051-1062.

[23] S. Aquino Neto, and A.R. de Andrade, Electrooxidation of glyphosate herbicide at different DSA compositions: $p H$, concentration and supporting electrolyte effect, in Electrochimica Acta, 2009, pp. 2039-2045.

[24] R.H. Myers, and D.C. Montgomery, Response Surface Methodology: Process and Product in Optimization Using Designed Experiments, John Wiley \& Sons, Inc., 1995. 


\section{Figure list}

Fig. 1. Effect of current intensity versus glyphosate degradation and mineralization rate (operating condition: $\mathrm{I}=0.5 \mathrm{~A}-10 \mathrm{~A}$, Initial glyphosate conc. $=16.9 \mathrm{mg} \mathrm{L}^{-1}, t=180 \mathrm{~min}$ )

Fig. 2. Variation of glyphosate and TOC concentrations versus treatment time (operating condition: $\mathrm{I}=5 \mathrm{~A}$, Initial glyphosate conc. $\left.=16.9 \mathrm{mg} \mathrm{L}^{-1}, \mathrm{t}=0-360 \mathrm{~min}\right)$

Fig. 3. Effect of $\mathrm{pH}$ versus glyphosate degradation and mineralization rate (operating condition: $\mathrm{I}=5 \mathrm{~A}$, Initial glyphosate conc. $\left.=16.9 \mathrm{mg} \mathrm{L}^{-1}, \mathrm{t}=120 \mathrm{~min}\right)$.

Fig. 4. Effect of initial glyphosate concentration: normalized glyphosate concentration (4a) and normalized TOC concentration (4b). (Operating condition: $\mathrm{I}=5 \mathrm{~A}$, Initial glyphosate conc. $=4.3-16.9 \mathrm{mg} \mathrm{L}^{-1}, \mathrm{t}=0-120 \mathrm{~min}$ ). 
Table 1

Properties of glyphosate

Herbicide

Glyphosate

Molecular structure

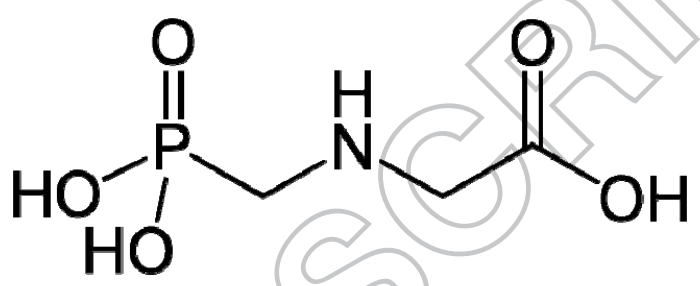

Molecular weight, $\mathrm{g} \mathrm{mol}^{-1}$

169.07

Solubility, $\mathrm{g} \mathrm{L}^{-1}$

10.1

$\log \mathrm{K}_{\mathrm{ow}}$

$\mathrm{LD}_{50}, \mathrm{mg} \mathrm{kg}^{-1}$

4230

Maximum acceptable concentration in fresh

0.8

water, $\mathrm{mg} \mathrm{L}^{-1}$ 
Table 2

Experimental range and levels of independent variables.

\begin{tabular}{cccccc}
$\begin{array}{c}\text { Coded } \\
\text { variables }\left(\mathbf{X}_{\mathbf{i}}\right)\end{array}$ & $\begin{array}{c}\text { Factor } \\
\left(\mathbf{U}_{\mathbf{i}}\right)\end{array}$ & Description & Min value $(-1)$ & Max value $(+1)$ \\
\hline $\mathrm{X}_{1}$ & $\mathrm{U}_{1}$ & Treatment time (min) & 90 & \\
$\mathrm{X}_{2}$ & $\mathrm{U}_{2}$ & Current (A) & 2 & 3.5 \\
\hline
\end{tabular}


Table 3

Central composite matrix and experimental results

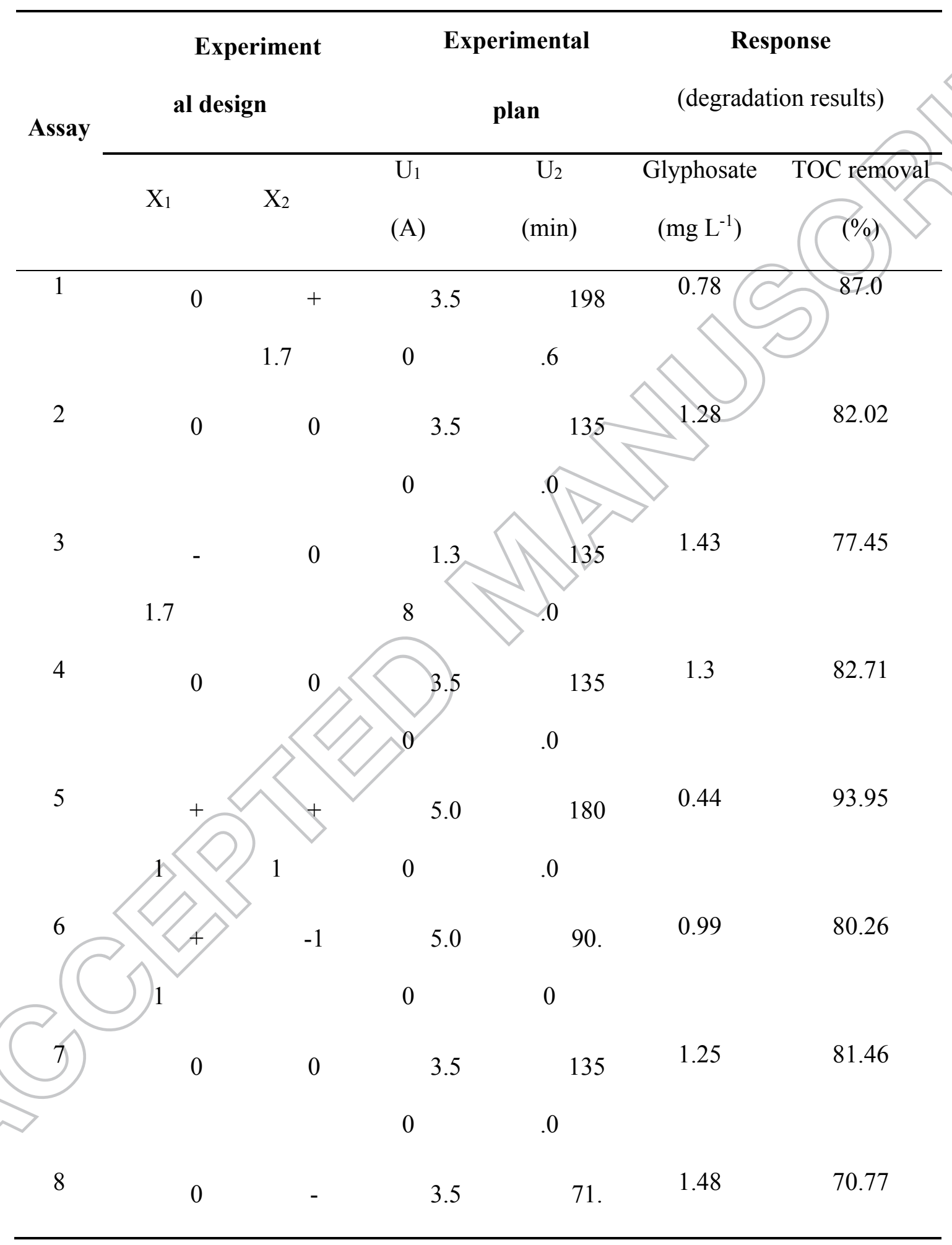


$1.7 \quad 0 \quad 36$

9

$\begin{array}{lllll}0 & 3.5 & 135 & 1.32 & 81.0 \\ & & & & \\ & & & & \end{array}$

10

$\begin{array}{lllll}0 & 3.5 & 135 & 1.26 & 82.1\end{array}$

$0 \quad .0$

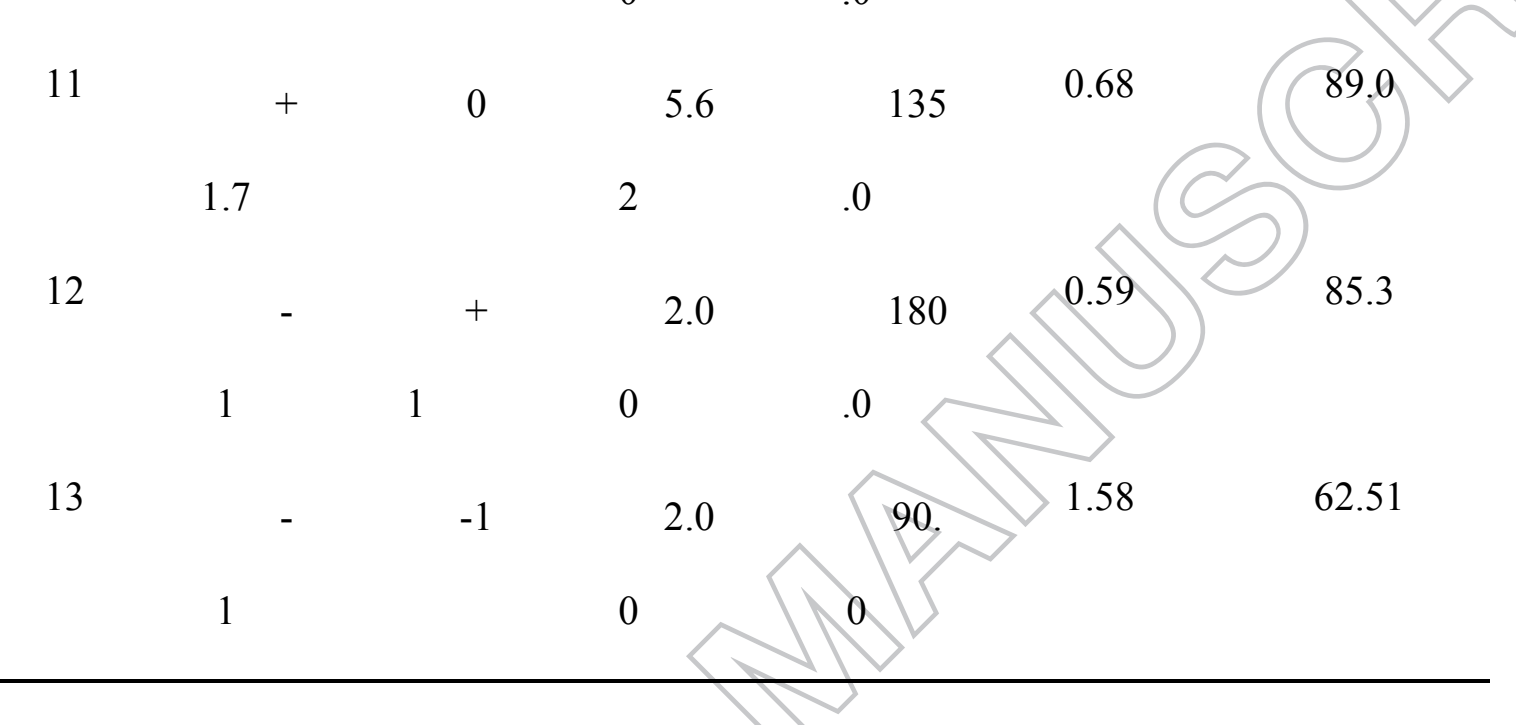

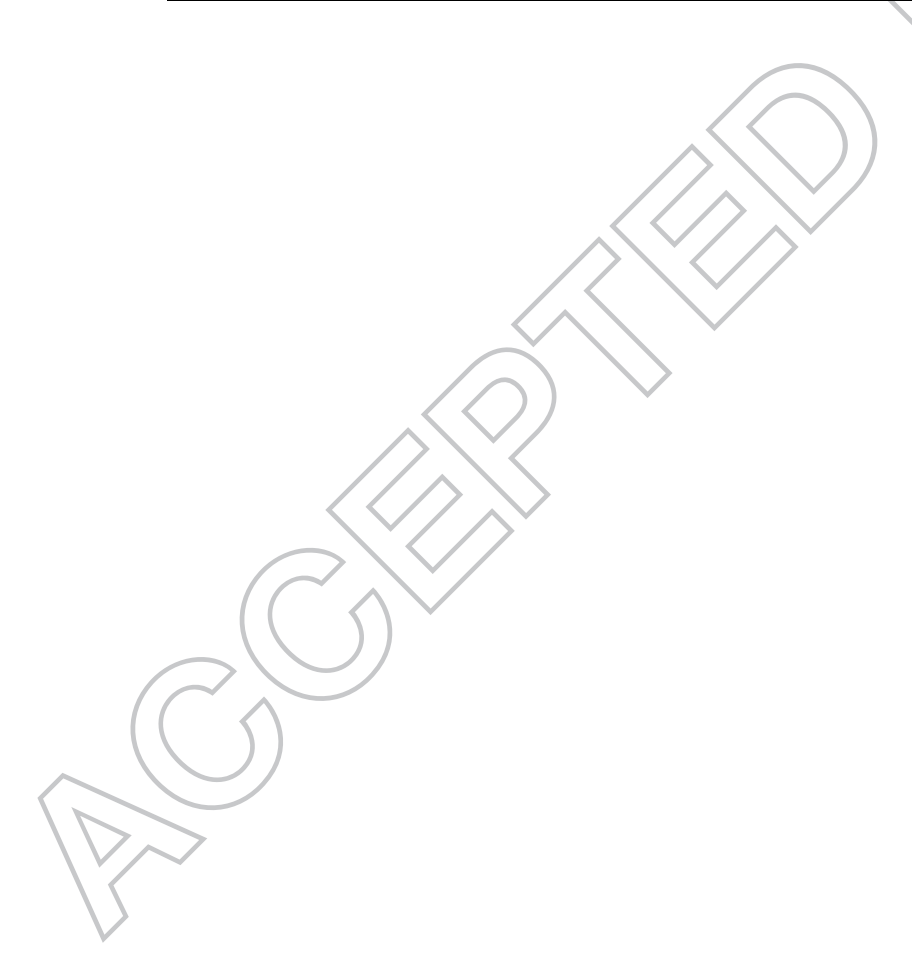


Table 4

Optimum operating conditions and experimental results.

Parameter

Optimal value and results

Operating condition

Treatment time, min

173

Current intensity, A

4.77

Glyphosate concentration, $\mathrm{mg} \mathrm{L}^{-1}$

16.9

Theoretical response:

- Glyphosate concentration, $\mathrm{mg} \mathrm{L}^{-1}$

- TOC removal, \%

Experimental results:

$\underline{\text { Influent }}$ (before treatment)

- $\mathrm{pH}$

- Glyphosate, $\mathrm{mg} \mathrm{L}^{-1}$

$4.2 \pm 0.5$

- $\mathrm{TOC}, \mathrm{mg} \mathrm{L}^{-1}$

$12.4 \pm 0.5$

- $\mathrm{P}_{\mathrm{PO}} 4, \mathrm{mg} \mathrm{L}^{-1}$

$2.007 \pm 0.05$

$<0.1$

- $\mathrm{N}_{\mathrm{NO} 3}, \mathrm{mg} \mathrm{L}^{-1}$

$0.048 \pm 0.02$

- $\mathrm{N}_{\mathrm{NH} 4}, \mathrm{mg} \mathrm{L}^{-1}$

$<0.01$

\section{Effluent (after treatment)}

- $\mathrm{pH}$

$4.0 \pm 0.5$

- Glyphosate, $\mathrm{mg} \mathrm{L}^{-1}$

$0.60 \pm 0.25$

- $\mathrm{TOC}, \mathrm{mg} \mathrm{L}^{-1}$

$0.1945 \pm 0.02$

- $\quad \mathrm{P}_{\mathrm{PO}}, \mathrm{mg} \mathrm{L}^{-1}$

$1.911 \pm 0.1$ 
- $\mathrm{N}_{\mathrm{NO} 3}, \mathrm{mg} \mathrm{L}^{-1}$

$0.775 \pm 0.04$

- $\mathrm{N}_{\mathrm{NH} 4}, \mathrm{mg} \mathrm{L}^{-1}$

$0.364 \pm 0.01$

Experimental response:

- Glyphosate removal, \%

95.16

- TOC removal, \%

90.31 

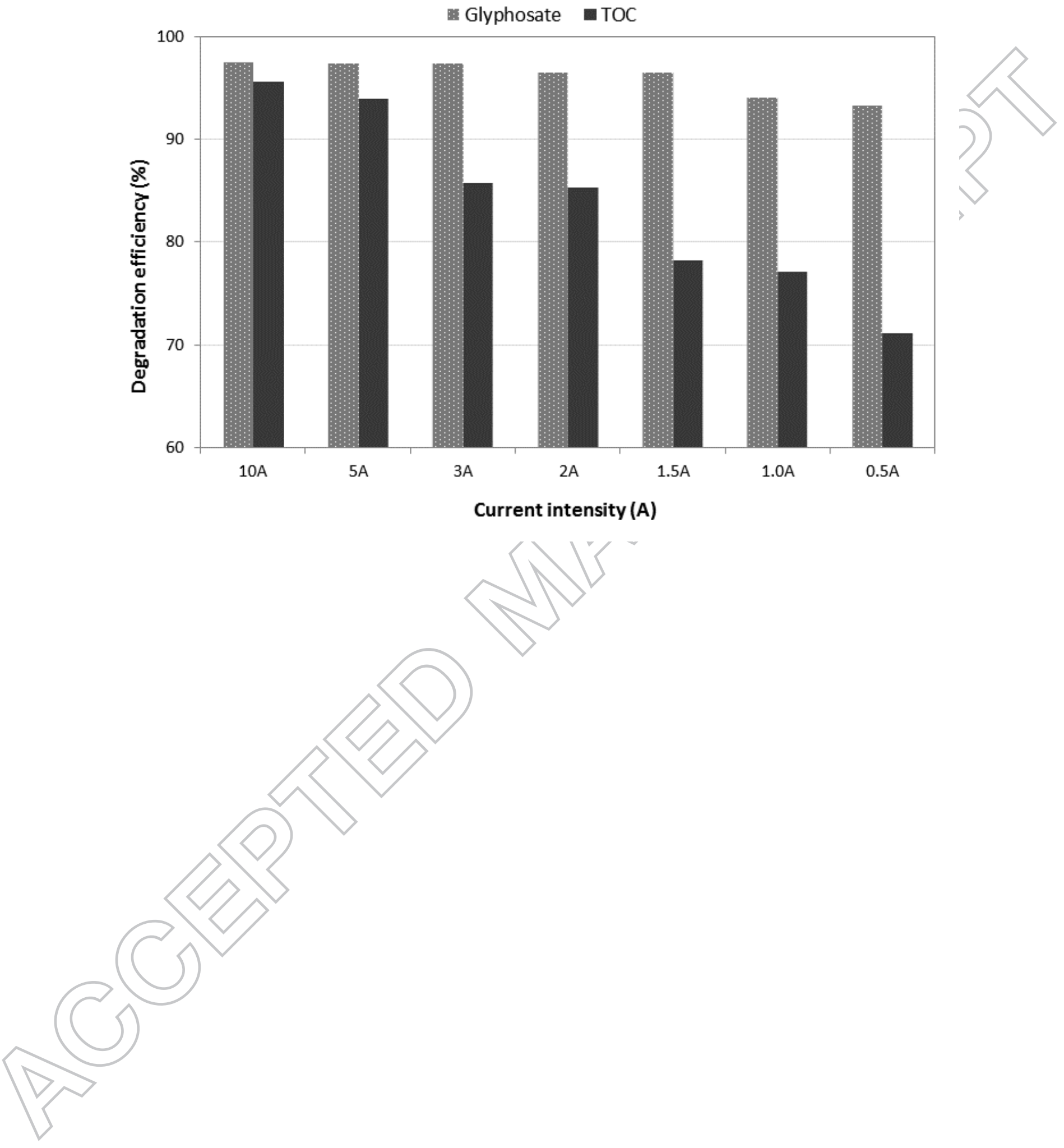

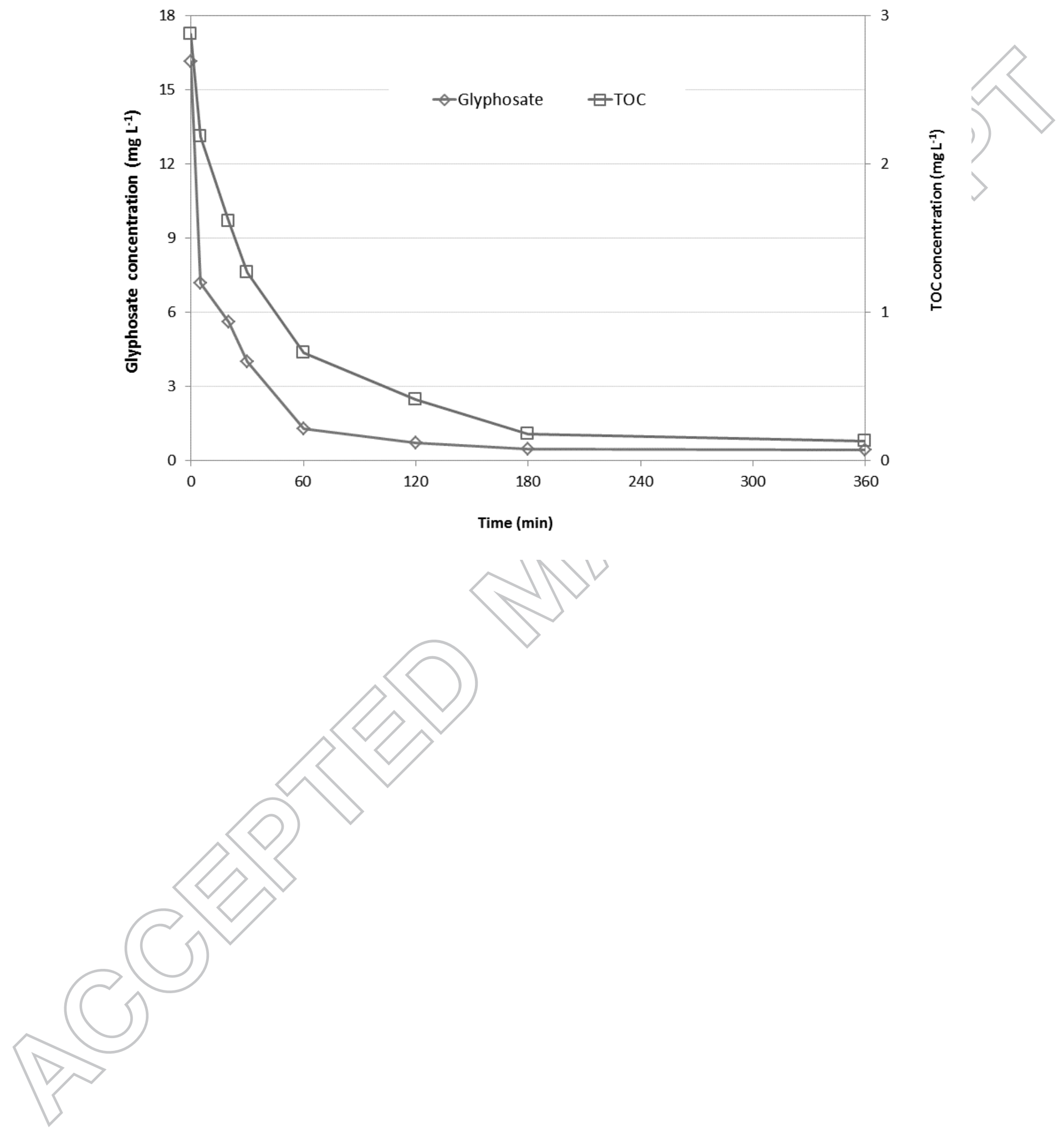

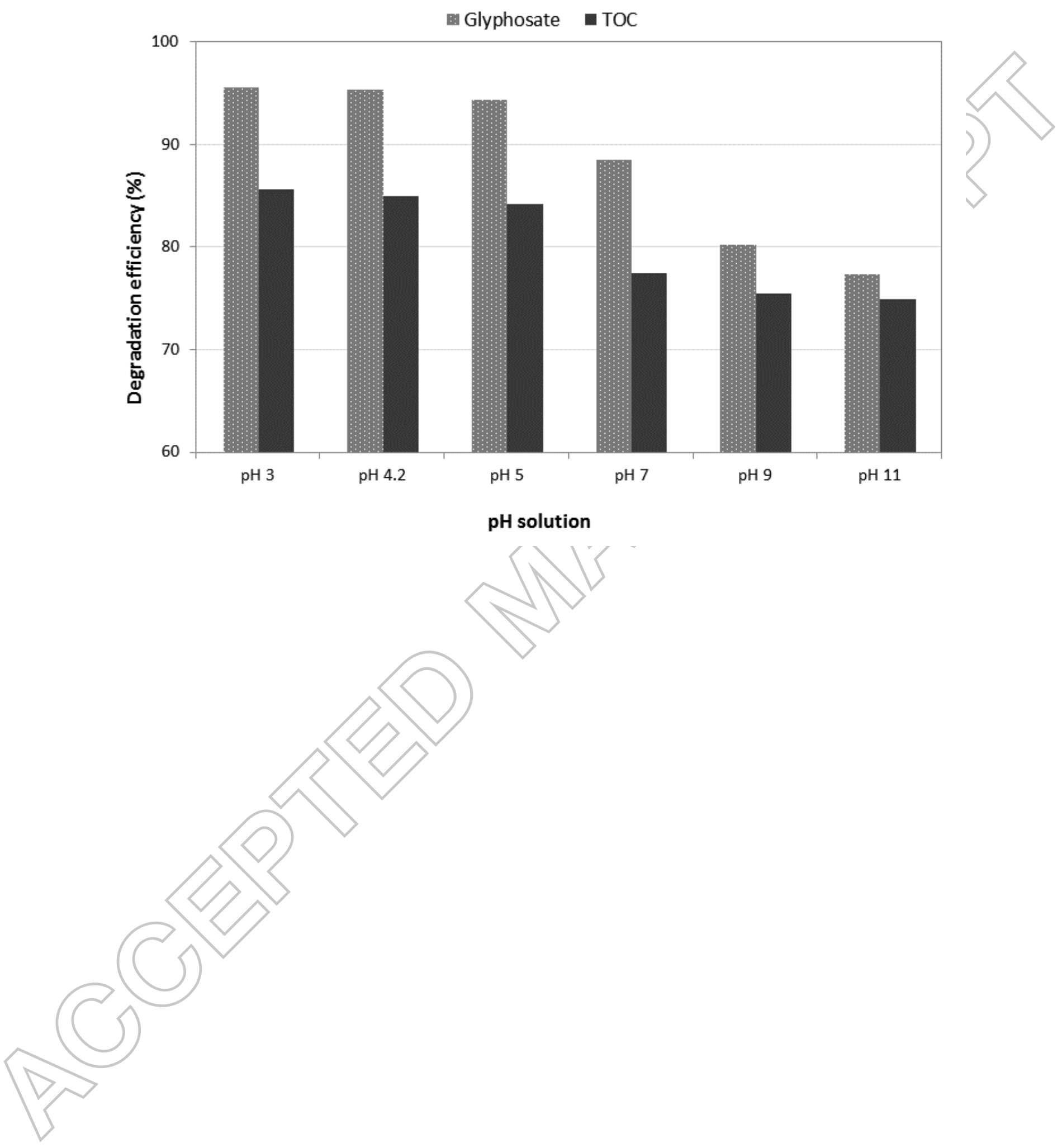

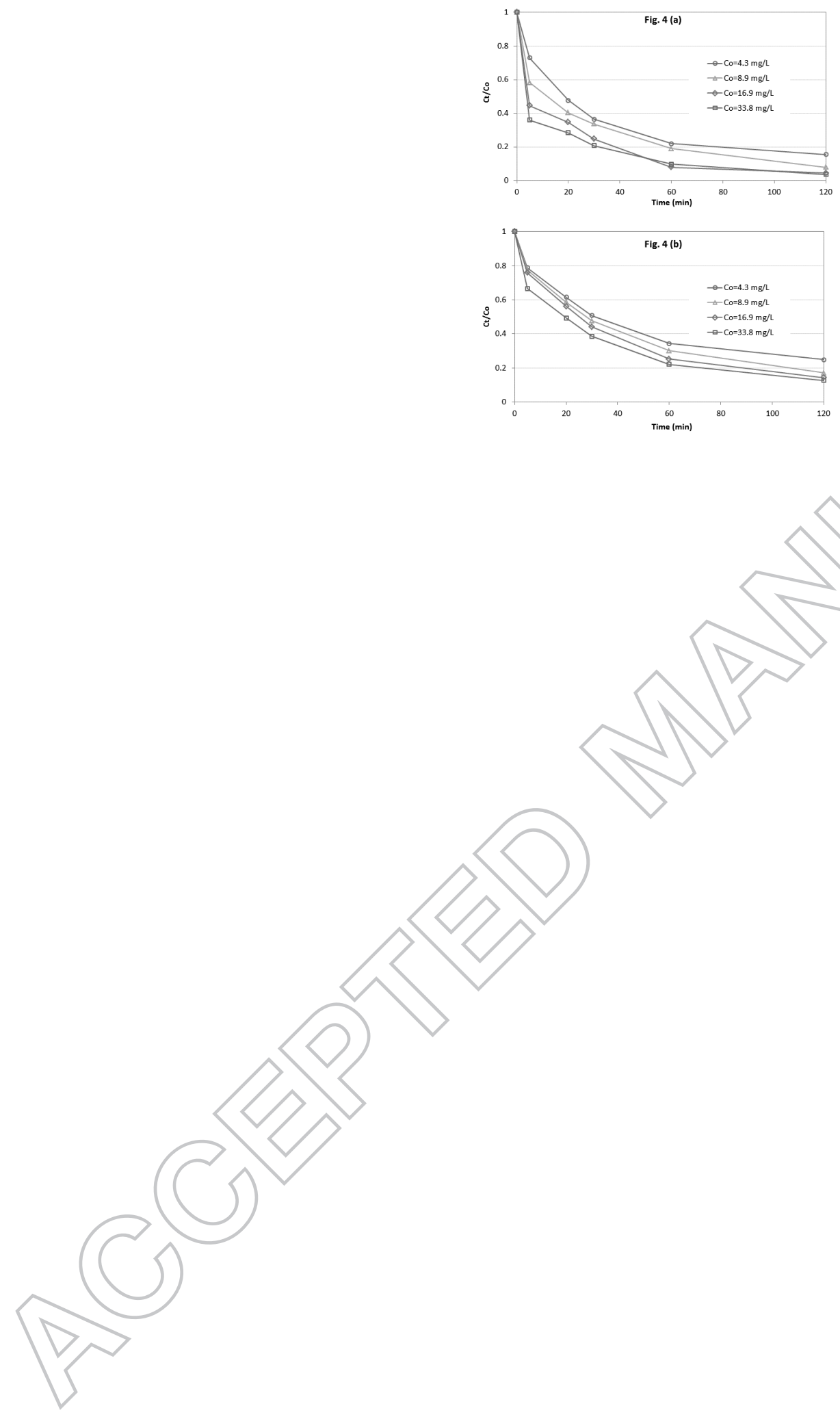